\title{
Surveillance of the Current Situation of Self-Employed People with Disabilities (On The Example of Mongolia)
}

\author{
Ariunbileg Sodnomdorj \\ Lecturer at Public Administration \\ Department in National University of Mongolia \\ Daariimaa Chuluunbaatar \\ Doctoral Candidate of Public Administration, Mongolian \\ University of Science and Technology
}

\section{Summary}

People with disabilities have always aspired to be active members of society while living and working in different ways. There are currently 107,075 people with disabilities in Mongolia, representing 3.3 percent of the total population as of 2019. The state policy on these citizens has been developed and implemented on a legal basis. Although governmental and non-governmental organizations and researchers have conducted extensive research on the employment of people with disabilities and assessed the results of law enforcement and other activities, there is still a lack of official surveys and statistics to determine the self-employment status of people with disabilities. The purpose of this article is to examine the current state of self-employment of people with disabilities, to determine the level of opportunities for selfemployment, and to draw the attention of policymakers, decision-makers, and other influential organizations working in this field. A survey of self-employed people with disabilities was conducted in late 2019 and early 2020, and other figures are based on 2019 statistics. The survey was based on interview methods, and interviews with speech and hearing-impaired people were conducted with the assistance of a sign language interpreter.

Keywords: disabled person, self-employment, informal worker, government policy and regulation

\section{Overview of people with disabilities in Mongolia}

In Mongolia, disability is a multi-sectoral issue, and the focus is on producing data that meets the needs of each sector. According to the Ministry of Labor and Social Welfare, there are 107,075 registered people with disabilities, or 3.3 percent of the total population, of whom 34,906 live in the capital, Ulaanbaatar ${ }^{1}$. The sex ratio is 42.9 percent for women and 57.1 percent for men, with 46,379 people with congenital and 60,696 people with acquired disabilities. According to the 2020 Population and Housing Census, the number of people with disabilities decreased by 1.6 percent to 106,363 in the late 2018 , accounting for 3.3 percent of the resident population, however. The data vary depending on the programs and activities for people with disabilities in Mongolia, as well as the different methods used to estimate any survey. As a result, there is a lack of a unified database of people with disabilities.The following figure is based on national statistical data.

Figure1. Number of people with disabilities and its percentage in the total population 2003-2019

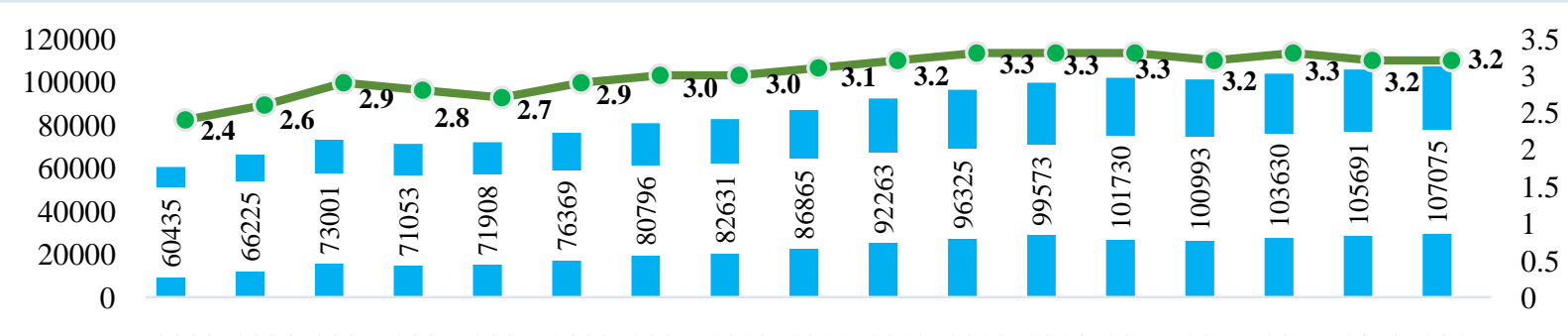

20032004200520062007200820092010201120122013201420152016201720182019

Number of people with disabilities $\quad-0-$ Persentage in the total population

\footnotetext{
${ }^{1}$ Ministry of Labor and Social Welfare, JICA, "Issues for People with Disabilities: Policies and Activities 2020: Information Directory", UB 2020, p15-17. 


\section{Source: National Statistical Office, 2019}

Considering the total population with disabilities in terms of types of disabilities, thepopulation with physical impairmentsis holding the maximum or 20.1 percent (21.5 thousand) and the population with speech disabilities is the smallest or 3.8 percent (4.1 thousand). In Ulaanbaatar, the population with mental disabilities is the largest at 19.1 percent $(7.1 \text { thousand) and the population with speech disabilities is the lowest at } 4.7 \text { percent (1.6 thousand })^{2}$.See Figure 2.

Figure 2.Types of disability of Mongolian people with disabilities ${ }^{3}$, 2009-2019

\begin{tabular}{|c|c|c|c|c|c|c|c|c|c|c|c|c|}
\hline \multicolumn{12}{|l|}{35000} & \multirow{13}{*}{$\begin{array}{l}\text { Visual } \\
\text { - Speech } \\
\text { - Hearing } \\
\text { - Physical } \\
\text { - Mental } \\
\text { - Combined } \\
\text { Other }\end{array}$} \\
\hline $\begin{array}{l}30000 \\
25000\end{array}$ & & & & & & & & & & & + & \\
\hline 20000 & & & & & & & 1 & 1 & & 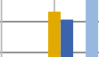 & & \\
\hline $\begin{array}{r}10000 \\
5000\end{array}$ & & & & & & & & & & & & \\
\hline & 2009 & 2010 & 2011 & 2012 & 2013 & 2014 & 2015 & 2016 & 2017 & 2018 & 2019 & \\
\hline Visual & 7794 & 8431 & 9066 & 9559 & 9559 & 9562 & 10925 & 11001 & 11071 & 11519 & 11690 & \\
\hline Speech & 6144 & 6012 & 5823 & 5628 & 5480 & 5294 & 4491 & 4367 & 4228 & 4312 & 4086 & \\
\hline Hearing & 7612 & 7709 & 7830 & 7935 & 8055 & 8304 & 8406 & 8560 & 8554 & 8439 & 8585 & \\
\hline Physical & 15501 & 15334 & 16178 & 17580 & 18351 & 18411 & 20110 & 20127 & 20688 & 21598 & 21545 & \\
\hline Ment & 7670 & & 0700 & 10080 & $15=40$ & & ר1019 & 10750 & & & חרסרט & \\
\hline & & & & & & & & & & & & \\
\hline Combined & 8758 & 8685 & 9833 & 9732 & 9571 & 10116 & 7912 & 8052 & 7842 & 7278 & 7334 & \\
\hline Other & 21403 & 21834 & 22433 & 24992 & 28760 & 30799 & 31453 & 30527 & 31514 & 32181 & 33107 & \\
\hline
\end{tabular}

Source: National Statistical Office, 2019

According to the Central Medical Labor Verification Commission under the General Department of Social Insurance, the number of people with disabilities is increasing by 2.2 percent annually. As of 2019, diseases of organs, systems and occupational diseases caused by human life including 18 groups of diseases that cause disability-mental, neurological, traumatic, ear and nose and throat diseases accounted for $76.01 \%$ of total disability and the leading cause of disability ${ }^{4}$. The number of people who have lost their ability to work due to internal diseases is the highest in the last 2 years (19.6 - 19.9 percent) ${ }^{5}$; The number of people with a disability is on the rise due to road transport, industrial and domestic related accidents, and 56.7 percent of the total population with disabilities considered to have acquired a disability(26 percent of people with disabilities are in agriculture, mining, education, and construction) ${ }^{6}$. In 2019 , the number of people with a fixed disability rate $^{7}$ was 111,386 , which is 3.5 percent of the total population ${ }^{8}$. Approximately, 72 percent of citizens with a fixed disability rate are 31-55 years old or working age ${ }^{9}$.

External risk factors for disability include domestic and industrial injuries, drug abuse, occupational safety, and poor hygiene. These risk factors are due to the fact that professional inspection bodies, trade unions and other organizations

\footnotetext{
${ }^{2}$ Ibid, p.18

${ }^{3}$ Depending on the WHO, there are six categories of disability: visual, speech, auditory, physical, mental, and others (other than these and combined).

${ }^{4}$ The Central Medical Labor Verification Commission under the General Department of Social Insurance, http://www.ndaatgal.mn/v1/view/1192

5 Ibid.

${ }^{6}$ Ibid.

${ }^{7}$ The percentage and duration of disability determined by a professional organization

${ }^{8}$ Ministry of Labor and Social Welfare, JICA, "Issues for People with Disabilities: Policies and Activities 2020: Information Directory", UB 2020, p23.

${ }^{9}$ The Central Medical Labor Verification Commission under the General Department of Social Insurance, http://www.ndaatgal.mn/v1/view/1192
} 
do not fully control the provision of a healthy and safe working environment, which leads to people with acquired disabilities ${ }^{10}$.

According to the national statistics in 2019 , the share of people with disabilities due to traffic accidents increased by 0.5 percent compared to the previous year, reaching 4.3 percent ${ }^{11}$.In general, statistics show that the number of people with hearing, speech and mental disabilities is higher for people with congenital disabilities, while the number of people with physical impairments is higher for people with acquired disabilities. See Figure 3.

\section{Figure 3.Causes of disability in Mongolia, 2009-2019}

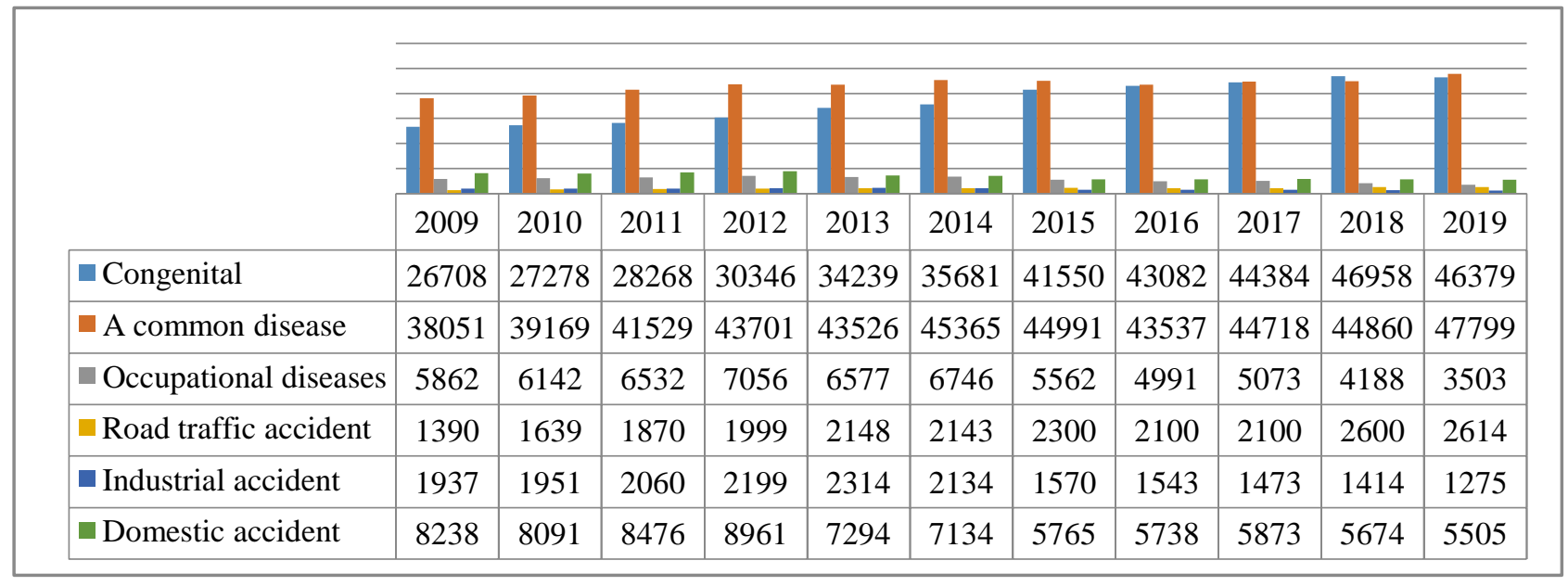

Source: National Statistical Office, 2019

\section{Mongolian social protection and support for people with disabilities}

In Mongolia, the social protection of peoplewith disabilities is regulated by a package of social welfare and social insurance laws. Furthermore, Mongolia has two social welfare funds: a pension fund and a social service fund ${ }^{12}$, in addition there are five social insurance funds: pension insurance fund; benefit insurance fund; health insurance fund; industrial accident and occupational disease insurance fund; unemployment insurance fund ${ }^{13}$. These are all independent directories.All people with disabilities are entitled to 19 types of benefits, of which 53.3 percent come from the social insurance fund and 46.7 percent from the social welfare fund ${ }^{14}$. Each person with a disability receives an average of MNT 924,000 a year as assistance and benefits ${ }^{15}$. This means that the state provides an average of MNT 80,000 per month, which is 0.7 percent of GDP (however, under COVID pandemic, monthly income increased by MNT 100,000).

The number of welfare pensioners who receive benefits from the Social Insurance Fund reached 68,475 which cost 231.9 million in 2019, an increase of 27.6 percent over the previous year ${ }^{16}$. In the same year, the Social Welfare Fund spent 74.2 billion MNT to provide disability pensions to 42,468 people with disabilities ${ }^{17}$.

Also, as social protection and support, the personal income of an employed person with a disability includes, in addition to wages and salaries, income from business activities, property or dividends, interest on bank deposits, income from the sale, and transfer of assets. These incomes are not taxed. For example, if a person with a disability holds a bank deposit has submitted a document proving that he or she has a disability to the bank, the bank will pay the

\footnotetext{
${ }^{10}$ Ibid.

${ }^{11}$ Number of traffic accidents and violations registered nationwide, http://transportation.police.gov.mn/as/statistic

${ }^{12}$ Social Welfare Law, 2012

${ }^{13}$ Law on social insurance, 1994

${ }^{14}$ IV Asia-Pacific Congress for Community-Based Development of People with Disabilities, Member of Parliament Oyunkhorol, "Reform of Mongolia's legal environment for an inclusive society for all people with disabilities within the framework of the Sustainable Development Goals and the implementation of the UN Convention on the Rights of People with Disabilities", Ulaanbaatar, 2019, p.69.

${ }^{15}$ Ibid.

${ }^{16}$ The National Statistical Office, Unified Statistical Database, 2019, http://1212.mn

${ }^{17}$ Ministry of Labor and Social Welfare, JICA, "Issues for People with Disabilities: Policies and Activities 2020: Information Directory", UB 2020, p30.

100
} 
deposit without tax. These methods are the forms of social protection and assistance provided to Mongolian people with disabilities.

\section{Employment of people with disabilities in Mongolia}

Mongolia has ratified the legal framework for the employment ofpeople with disabilities and is a party to more than 20 international conventions and protocols governing the Universal Declaration of Human Rights and related sectoral relations, as well as a total of 35 laws and regulations internally. More than a dozen policy documents and programs are also being implemented. Some of these include Article 111.1 of the Labor Law (1999), which stipulates that a business entity or organization with twenty-five or more employees may employ a person with a disability in four or more percent of its positions; According to Article 17.5 of the Law on the Rights of People with Disabilities, adopted in 2016, "It is prohibited to suspend any social welfare and social insurance pensions and benefits for people with disabilities who are employed for paid reasons" and continue to receive pensions and benefits from the social insurance fund and social welfare fund, if any; According to Article 25.3 of the Personal Income Tax Law (revised 2019), "Withholding tax shall be deductible on the basis of evidence relevant to the imposition of personal income tax on people with disabilities" and all income of people with disabilities is exempt from personal income tax. The following table categorizes the laws and legal documents related to ensuring the right to work of people with disabilities in Mongolia.See Table 1.

Table 1. Applicable law, the right to employment for PWDs

\begin{tabular}{|c|c|c|}
\hline № & $\begin{array}{l}\text { The content of the laws } \\
\text { related to the Right to } \\
\text { work }\end{array}$ & Law and regulations \\
\hline 1 & $\begin{array}{l}\text { Laws related to } \\
\text { employment promotion }\end{array}$ & $\begin{array}{l}\text { Labor Law, } 1999 \\
\text { Law on Employment Promotion, } 2011 \\
\text { Law on Social Protection of People with Disabilities, } 2005 \\
\text { National Program for the Rights, Participation and Development of People with } \\
\text { Disabilities, Medium-Term Policy Document, } 2017 \\
\text { Job Support Program for People with Disabilities, } 2017\end{array}$ \\
\hline 2 & $\begin{array}{l}\text { Laws related to work and } \\
\text { working environment, } \\
\text { labor protection and } \\
\text { hygiene }\end{array}$ & $\begin{array}{l}\text { Constitution of Mongolia, } 1992 \\
\text { Corporate Income Tax Law, } 2019 \\
\text { Construction Law, } 2016 \\
\text { Law on Urban Development, } 2008 \\
\text { Law on Road Transport, } 1999 \\
\text { Law on Occupational Safety and Health, } 2008 \\
\text { Space that takes into account the needs of people with disabilities in civil construction } \\
\text { planning, MNS } 91.040 .10 \text { standard }\end{array}$ \\
\hline 3 & $\begin{array}{l}\text { Laws related to } \\
\text { vocational training, } \\
\text { capacity building, self- } \\
\text { development } \\
\text { empowerment }\end{array}$ & $\begin{array}{l}\text { Labor Law, } 1999 \\
\text { Law on Social Protection of People with Disabilities, } 2005 \\
\text { Law on Employment Promotion, } 2011 \\
\text { Law on Education, } 2016 \\
\text { Law on Vocational Education, } 2009\end{array}$ \\
\hline 4 & $\begin{array}{l}\text { Laws related to employer } \\
\text { support }\end{array}$ & $\begin{array}{l}\text { Labor Law, } 1999 \\
\text { Law on Social Protection of People with Disabilities, } 2005\end{array}$ \\
\hline
\end{tabular}

Source: Disability Studies as an Interdisciplinary Science, 2018.

According to the UN Convention on the Rights of People with Disabilities and other laws, the rights of people with disabilities are legally guaranteed to a certain extentin Mongolia.However, it is important to pay special attention to their special needs, such as realizing their rights in depth, not being a caretaker, being independent of anyone in charge, living contentedly, and earning enough to meet their needs, and to organize government support in an efficient and accessible manner. 
Today, only 30.8 percent or 32,759 people with disabilities are employed, that is 2.8 percent of the total employed population of Mongolia. Of these, 61.2 percent or 20,048 were men and 38.8 percent or 16,789 were women ${ }^{18}$. Of these, 60.8 percent or 18,717 were men and 39.2 percent or 12,031 were women.

By age group, 6,031 were aged 15-34, of which 3,607 were male; 24,393 aged 35-69, of which 14,986 were male; there were 324 people over the age of 70 , including $124 \mathrm{men}^{19}$.

According to a survey conducted by the Labor and Social Welfare Research Institute in 2018, 28 percent of employees with disabilities are combined, 21.6 percent are physical, 13.2 percent are auditory, 8.1 percent are visual, 7.3 percent are speech, 5.0 percent had mental health problems and 16.8 percent had other disabilities. This is summarized in Table 2 .

Table 2. Employed people with disabilities: Type of disabilities, persontage ${ }^{20}$

\begin{tabular}{|l|l|r|}
\hline № & Employed people with disabilities: Type of disabilities & $28,0 \%$ \\
\hline 1 & Employee with combined difficulties & $21,6 \%$ \\
\hline 2 & Employee with physical disabilities & $13,2 \%$ \\
\hline 3 & Employee with hearing impairment & $8,1 \%$ \\
\hline 4 & Visually impaired worker & $7,3 \%$ \\
\hline 5 & Employee with speech problems & $5,0 \%$ \\
\hline 6 & Employee with a mental disability & $16,8 \%$ \\
\hline 7 & Other disabled workers & \\
\hline
\end{tabular}

Source:Labor and Social Welfare Research Institute, 2018.

No detailed employment survey of people with disabilities has been conducted since the first month of 2019, and the Population and Housing Census 2020 estimates employment by the UN Washington Group method. People with disabilities are developing on the basis of the idea of equal participation in social relations, employment, and equal pay, just like people without disabilities in Mongolia. In line with this, the UN Washington Group's standard short questionnaire was used in the 2020 Population and Housing Census to increase the international comparability of disability data. The short set of questionnaire questions identifies difficulties in six sets of activities: sight, hearing, walking, self-care, communication, and memory. Complications are calculated for the population aged 18 and over, according to the Washington Group's short survey recommendations. In this case, at least one of the six operational responses is answered as "very difficult" or "not at all". See Table 3.

Table 3. Employment status of the population aged 18 and over, employment status, types of operational difficulties, percentage of results, 2020

\begin{tabular}{|c|c|c|c|c|c|c|c|}
\hline \multirow{2}{*}{ Total } & & \multicolumn{6}{|c|}{ By duplication of operational difficulties } \\
\hline & & 1 & 2 & 3 & 4 & 5 & 6 \\
\hline \multicolumn{8}{|l|}{ Whether working or not } \\
\hline Total & 100.0 & 100.0 & 100.0 & 100.0 & 100.0 & 100.0 & 100.0 \\
\hline Employed & 31.2 & 39.4 & 24.9 & 14.2 & 9.5 & 6.8 & 7.0 \\
\hline Unemployed & 68.8 & 60.6 & 75.1 & 85.8 & 90.5 & 93.2 & 93.0 \\
\hline \multicolumn{8}{|l|}{ Employment status } \\
\hline Total & 100.0 & 100.0 & 100.0 & 100.0 & 100.0 & 100.0 & 100.0 \\
\hline Full-time employee & 23.9 & 26.4 & 16.1 & 14.9 & 16.1 & 9.5 & 27.8 \\
\hline Temporary worker & 13.0 & 13.5 & 13.0 & 10.4 & 3.6 & 4.8 & - \\
\hline Part-time worker & 1.3 & 1.4 & 1.1 & - & - & - & - \\
\hline Paid apprentices and intern & 0.1 & 0.1 & - & - & - & - & - \\
\hline Contractor & 0.3 & 0.3 & 0.2 & - & - & - & - \\
\hline
\end{tabular}

\footnotetext{
${ }^{18}$ Information from the General Agency for Development of People with Disabilities, Policy Implementation AgencyMongolia, 2019

${ }^{19}$ Ibid.

${ }^{20}$ Author:The Department of Policy Implementation of the General Directorate of Labor and Social Welfare has provided general data as it has not yet released the full results of the employment survey this year. No detailed employment survey of people with disabilities has been conducted since the first month of 2019, and the UN Population and Housing Census 2020 estimates employment by the UN Washington Group method.
}

102 


\begin{tabular}{|l|r|r|r|r|r|r|r|}
\hline Entrepreneurial employer & 0.2 & 0.2 & 0.2 & 0.7 & - & - & - \\
\hline Market-oriented household enterprise employer & 0.4 & 0.4 & 0.2 & - & - & - & - \\
\hline An entrepreneur who does not have a paid employee & 0.5 & 0.6 & 0.6 & - & - & - & - \\
\hline $\begin{array}{l}\text { Market-oriented household enterprise operator who does not } \\
\text { have a paid employee }\end{array}$ & 47.3 & 44.8 & 55.9 & 51.9 & 57.1 & 71.4 & 50.0 \\
\hline Contributing family member & 13.0 & 12.3 & 12.7 & 22.1 & 23.2 & 14.3 & 22.2 \\
\hline
\end{tabular}

Source: Population and Housing Census.

According to the census, 31.2 percent of the total number of people with disabilities is registered as employed, 47.3 percent of them are self-employed, 23.9 percent are full-time, and 13.0 percent are temporary workers. The majority of households are self-employed. However, there are very few entrepreneurs, employers, apprentices and interns. This suggests that as duplication increases, the employment decreases.

Under the Law on Employment Promotion of People with Disabilities, the National Employment Council approved the "Employment Support Program for People with Disabilities" in 2017 and allocated 4.5 billion MNT to the fund in 2018. During the implementation of the program in 2019, a total of 5,622 citizens were covered and 3,542,869.6 thousand MNT was spent and 1161 jobs were created ${ }^{21}$. This figure is not sufficient, but it may be reasonable compared to Mongolia's overall unemployment rate ${ }^{22}$.

\section{Classification (based on the interviews)of current employment}

It would be more appropriate to classify the current realities of employment of people with disabilities into formal and informal employment; employment of people with congenital and acquired disabilities; and the relationship between employers and workers with disabilities. These differences provide a more realistic picture based on the findings of the interviews with people with disabilities.

Formal and informal employment:People with disabilities have relatively limited access to formal employment in government, non-government and private organizations. For example, according to the end-of-year results of the Civil Service Council in 2019, there are 1 visually impaired person, 4 people with physical impairments, 4 people with other types of disabilities, and a total of 9 people with disabilities working in 13 ministries. There are 3 people with disabilities working in the Ministry of Labor and Social Welfare which leads all public administration organizations. Only 0.01 percent of the total number of people with disabilities is working in the civil service ${ }^{23}$.

The negative attitudes of employers, such as the lack of interest of employers in the employment of people with disabilities, and their doubts about their contribution to the organization's productivity, are a major problem. Conversely, this attitude of employers pushes them to work informally.Informal employment manifests itself in the form of low-income or unpaid participation in household production and services.In other words, an informal employer is an employee who is working in an informal workplace. Informal employment includes the employment of individuals, households, and groups that are not fully covered by official registration, information, or social protection, are not part of any official organization, or the work is not prohibited by law ${ }^{24}$. Informal workers include:

1) A paid employee whose employment relationship is not fully regulated by law, income tax, sickness benefits, annual leave, or other social security regulations are not fully met;

2) Employers of market-oriented household enterprises working in the informal sector and self-employed without paid employees;

3) A paid worker in a household that produces products for its own end use only;

4) A family member who contributes to family income ${ }^{25}$

The international conferences' speeches such as the Ministry of Labor and Social Welfare, JICA International and other research universities jointly organized a conference on "Disability Studies as an Interdisciplinary Science" in 2018; and "Community-Based Development of People with Disabilities" the report of the Fourth Asia-Pacific Congress, under

\footnotetext{
${ }^{21}$ Ministry of Labor and Social Welfare, JICA, "Issues for People with Disabilities: Policies and Activities 2020: Information Directory", UB 2020, p35.

${ }^{22}$ As of 2019 , the unemployment rate was $10 \%$, http://nda.gov.mn/1177.html

${ }^{23}$ Annual report of the Civil Service Council and Sub-Council of Ministries, 2019

${ }^{24}$ State policy on informal employment, Annex to the Resolution No. 1 of the Parliament of Mongolia of 2006

${ }^{25}$ National Statistical Office, Methodology and Handbook for Calculating Employment Statistics 2019, p.16
} 
the auspices of the Prime Minister of Mongolia in 2019 - specified the need to pay more attention to the informal employment of people with disabilities. For example, Farida Yesmin,the Secretary of the Bangladesh Disability Rehabilitation Research Association (DRRA), said,

"People with disabilities in Mongolia are four times more likely to be employed in the informal sector than people without disabilities. Informal employment is more a matter of necessity than a matter of choice" 26 .

While this informal employment is unfair to people with disabilities (the informal sector tends to generate the shadow economy, unregistered and uncontrolled are risky, and do not account for a percentage of GDP ${ }^{27}$ ), it is still difficult for them to overcome informality unless the proper employment regulation.

Although a certain percentage of people who describe themselves as "self-employed" work without pay, they consider running a small private farm (for example, herding or growing vegetables in their yard) as "self-employment" the report 2018 said $^{28}$. Table 4 shows the current employment status and rate of people with disabilities aged 15 and over. As shown in this table, the percentage of the self-employed is high (41.6\%), but it is likely that this includes informal workers.

Table 4. Employment status and percentage of people with disabilities aged 15 and over ${ }^{29}$

\begin{tabular}{|l|l|r|}
\hline № & Employment status & Percentage \\
\hline 1 & Self-employed & $41,6 \%$ \\
\hline 2 & Employers with disabilities & $1,6 \%$ \\
\hline 3 & Paid worker & $35,7 \%$ \\
\hline 4 & Unpaid participant in household production and services & $20,1 \%$ \\
\hline
\end{tabular}

Source: Disability Studies as an Interdisciplinary Science, 2018

\section{Employment of people with congenital and acquired disabilities}

Observations show that the employment rate of people with acquired disabilities was relatively high ${ }^{30}$. During the interviews with people with disabilities, an interesting trend was observed in people with acquired disabilities compared to people with congenital disabilities. Because people with acquired disabilities have been active participants in society in the past, an inactive life is a "difficult" issue for them to reconcile. They are more willing to engage in at least informal but voluntary activities, such as growing vegetables, raising chickens and pigs, and running their own businesses. Overall, it seemedthat, regardless of their congenital or acquired disabilities, they have a desire to work. Table 5 compares the number of people with congenital and acquired disabilities.

Table 5. Number of people with disabilities aged 15 and over, employment, type of disability, percentage, 2019

\begin{tabular}{|l|r|r|r|}
\hline Type of disability & Total / number / & Employed / number / & $\begin{array}{l}\text { Unemployed } \\
\text { / number / }\end{array}$ \\
\hline Total & 107,075 & 32,759 & 74,316 \\
\hline People with congenital disabilities & 46,379 & 8,487 & 37,892 \\
\hline People with acquired disabilities & 60,696 & 12,321 & 48,375 \\
\hline
\end{tabular}

Source: General Agency for Development of People with Disabilities, Policy Implementation Agency, 2019

The relationship between employers and workers with disabilities

\footnotetext{
${ }^{26}$ IV Asia-Pacific Congress for Community-Based Development of People with Disabilities, Plenary Session Report, UB, 2019, p.56.

${ }^{27}$ Government Policy on Informal Employment, 2006

${ }^{28}$ Labor and Social Welfare Research Institute, Disability Studies as an Interdisciplinary Science, Proceedings of the Scientific Conference, 2018, p.227.

${ }^{29}$ Ibid.

${ }^{30}$ Ch. Daariimaa. MUST-School of Business Administration, Humanities, Survey on Visually Impaired People, 2018 104
} 
In 2017, there were 3340 enterprises paying social insurance premiums and employing people with disabilities in Mongolia, but as of September 2018, the number has increased to 3969. According to the survey, a total of 7,199 people with disabilities are paid employees, and pay social insurance premiums, currently ${ }^{31}$.

49.6 percent of organizations that provide jobs for people with disabilities and pay social insurance premiums operate in the capital city of Ulaanbaatar and 50.4 percent in rural areas ${ }^{32}$. There is no difference between the salaries of ordinary employees and employees with disabilities, but the salary rate they may vary depending on the organization's internal regulations and salary levels. This is an important indicator that creates favorable conditions and opportunities for people with disabilities to work and take their place in society and live independently ${ }^{33}$.

Employment of People with disabilities (PWDs) is, firstly, a sign that the organization is complying with the law, secondly, it proves that it is a socially responsible organization, and thirdly, it has the advantage of providing tax benefits by employing the special-need person. However, the fact that the reasons not employing the people with disabilities are, firstly, unsuitable for workplaces such as stairs, elevators, toilets, entrances, and exits are not equipped, and secondly, due to the inability to withstand the workload, slow business and low productivity of people with disabilities.

According to a study by the Labor and Social Welfare Research Institute, there are a number of reasons why people with disabilities do not get employed, terminated, or leave work on their own. These include poor access to job advertisementsand information; lack of knowledge and skills as an individual can have a negative impact on selfesteem; however, the main reason for dismissal in any organization is the difficulty of infrastructures, such as unsuitable conditions for public transport, roads, and construction.On the other hand, misunderstandings and some degree of discrimination in the workplace ${ }^{34}$ are the main causes for dismissal. Although quotas are set and enforced in labor laws, researchers believe that the reasons for the unemployment of people with disabilities are largely related to social and employer attitudes.

Salary and income: As of the first nine months of 2018, 39.7 thousand people were covered by the Law on Social Welfare and the Law on the Rights of People with Disabilities, and 46.7 billion MNT ${ }^{35}$ was spent. However, 25.3 thousand people were covered and 5.0 billion MNT was spent on assistance and benefits for people with disabilities ${ }^{36}$. According to the Law on Pensions and Benefits from the Social Insurance Fund, 19.8 billion MNT will be allocated for disability pensions in 2018, 2.1 billion MNT for 544 people for the loss of the breadwinner, and 15.6 billion MNT for other pensions and benefits. As of March 2020, MNT 76,316.4 million was spent on social welfare pensions and benefits, of which MNT 19,392.7 million was planned for disability pensions. In other words, in 2015, a person with a disability received apension of MNT 126,500 per month ${ }^{37}$, but it has gradually increased to MNT 188,000 by 2020, in line with the $\operatorname{law}^{38}$.

As of 2018, the average salary of people with disabilities was 546.3 thousand MNT, which is twice less than the national average salary $(1025.6)^{39}$. For example, the average monthly income of a family with visually impaired (2018) households with 1-3 members were MNT 180-350 thousand, households with four to six members were MNT 400-550

\footnotetext{
${ }^{31}$ Author: Quantitative research on the employment of people with disabilities may vary depending on the organization. For example, there are discrepancies between the data of the Social Security Research Institute, the Ministry of Social Welfare, and statistics. This text is based on data from the Statistical Office.

${ }^{32}$ Labor and Social Welfare Research Institute, Disability Studies as an Interdisciplinary Science, Proceedings of the Scientific Conference, 2018, p.228.

${ }^{33}$ Organizations to support the employment of people with disabilities and provide them with benefits provided by law; Law on Social Welfare of Citizens with Disabilities, 2005, Article 8.1.

${ }^{34}$ Labor and Social Welfare Research Institute, Disability Studies as an Interdisciplinary Science, Proceedings of the Scientific Conference, 2018, p.289.

${ }^{35}$ Currently, USD 1 equals MNT 2820-2850

${ }^{36}$ On the issue of increasing pensions for people with disabilities, Unuudur newspaper, December 11, 2018,http://unuudur.mn/

${ }^{37}$ Interactive LLC, Social Welfare Information System, 2015

${ }^{38}$ Survey participant Byambasuren, Labor and Welfare Service Specialist, Songinokhairkhan District, April 5, 2020

${ }^{39}$ Labor and Social Welfare Research Institute, Disability Studies as an Interdisciplinary Science, Proceedings of the Scientific Conference, 2018, p.248.
} 
thousand, and households with more than six members wereMNT 550-700 thousand ${ }^{40}$. According to this information, the average monthly salary of a disabled person is MNT 500-700 thousandwhichequalsUSD 175-320.

People with disabilities receive pensions and benefits from Government, but are still financially dependent on their family members. The main reasons for being a financial dependence are, firstly, the vast majority of the population is able and willing to work but not employed; second, it is directly related to the fact that pensions from the social insurance fund and benefits from the social welfare fund are insufficient for living.

Statistics also show that the poverty rate of households with PWDs is twice as high as that of other households, with $70 \%$ of PWDs unemployed, 50\% of PWDs aged 6-18 not attending school, and illiterate ${ }^{41}$.

\section{Self-employment of people with disabilities}

The employment rate of people with disabilities is shown in Table 4, with the highest rate of self-employment at 41.6\%. This indicator suggests that people with disabilities are more likely to be self-employed. To confirm this indication, a survey of self-employed people with disabilities was conducted in the first quarter of 2020.The result of the survey showed that the followings are the key to resolving the current unhappy situation:a/vast majority of PWDs are satisfied with their self-employment;b/being a private entrepreneur is a way to thrive; c/to take their place in society as a human being; and d/not to be inactive person, relying on someone or a state welfare program.People with disabilities of working age are more interested in running a private businessbeautysalon, kiosk, computer service, etc.), running a small production workshop (sewing, embroidery, car tire repair, etc.) and working in the retail sector than working in an organization.

A total of 51 self-employed PWDs participated in the survey. The majority of self-employed people with disabilities, or 66.6 percent were men and 33.3 percent were women. In terms of age, 53.3 percent were 26-45 years old, 33.2 percent were 15-35 years old, and 26.6 percent were 45-60 years old. As for the location of employment, $64 \%$ are in Ulaanbaatar and $36 \%$ are in rural areas. The result of the survey showed one interesting statistic which was 15 percent of the self-employed peoplewere employers and employ between 1 and 10 employees. The remaining 85 percent are self-employed or co-employed (pay no-one) people in order to ensure their own and family members' needs. In addition, 30 percent of the self-employed work for more than eight hours, 50 percent work 6-8 hours, and about 20 percent work less than six hours daily.

The total number of self-employed PWDs surveyed, and 53 percent of them work in manufacturing, 26 percent is in the service, 16 percent is in the trade, and the remaining 5 percent is in agriculture. Detailed rates for these four sectors are shown in Table 6.

\section{Table 6. Sectors and share of self-employed people with disabilities}

\begin{tabular}{|c|c|c|c|}
\hline \multicolumn{4}{|c|}{ Sectors and share of self-employed people with disabilities } \\
\hline Manufacturing (53\%) & Service $(26 \%)$ & Trade $(16 \%)$ & Agriculture (5\%) \\
\hline $\begin{array}{l}\text { Sewing (48\%) } \\
\text { Leather goods }(15.5 \%)\end{array}$ & $\begin{array}{l}\text { Car tire repair }(61 \%) \\
\text { Beauty }(15 \%)\end{array}$ & $\begin{array}{l}\text { Trade: retail store, kiosk } \\
\text { operation }(36 \%)\end{array}$ & $\begin{array}{l}\text { Vegetable cultivation } \\
(70 \%)\end{array}$ \\
\hline $\begin{array}{l}\text { Wood products and } \\
\text { handicrafts }(11.5 \%)\end{array}$ & $\begin{array}{l}\text { Computer service / canon } \\
/(24 \%)\end{array}$ & $\begin{array}{l}\text { Grocery store }(17 \%) \\
\text { Street trading on hand }\end{array}$ & $\begin{array}{l}\text { Plant and flower } \\
\text { cultivation }(30 \%)\end{array}$ \\
\hline $\begin{array}{l}\text { Embroidery-Felt Crafts } \\
(16, \%) \\
\text { Food production }(9 \%)\end{array}$ & & $(47 \%)$ & \\
\hline
\end{tabular}

Source: Survey, Q1 2020

These self-employed people are classified according to their type of disability:

- $\quad 71 \%$ or most of the employees in the manufacturing sector have hearing and speech impairments;

- $\quad 42 \%$ of workers in service have physical impairments and 39\% have hearing and speech impairments;

- $\quad 35.5 \%$ of workers in trade are visually impaired and $32 \%$ are visually impaired;

- $\quad 47.5 \%$ of those working in the agricultural sector are people with combined-disabilities and $43 \%$ are people with other disabilities.

\footnotetext{
${ }^{40}$ Ibid.

${ }^{41}$ IV Asia-Pacific Congress on Community-Based Development of People with Disabilities, Plenary Session Report, UB, 2019, p.68.
} 
This evidence can be used to assess which people with disabilities work in which sectors, and to provide advice and training on which people can work or run businesses, depending on the type of disability. See Figure 6.

Figure6.Sectors of the self-employedPWDs and the type of disability

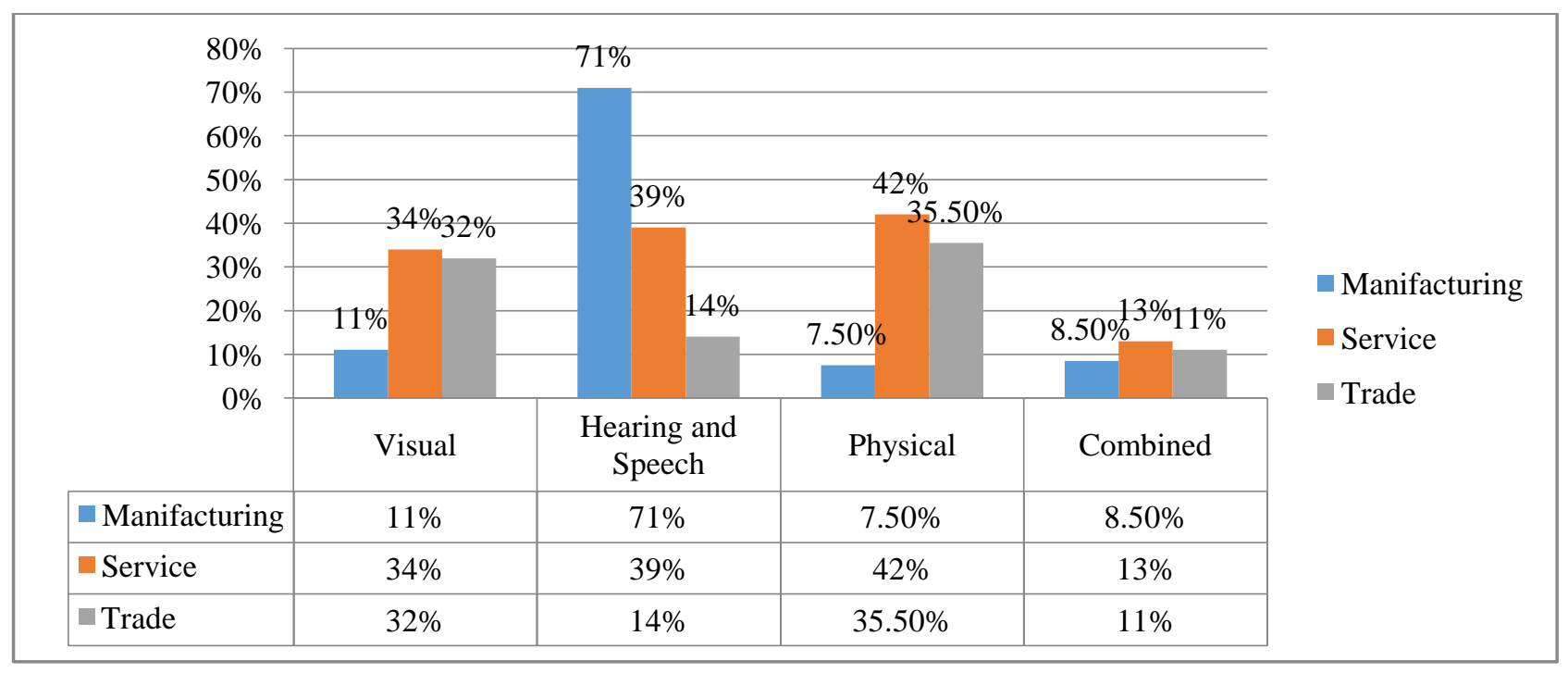

Source: Author

Self-employed people with disabilities face the same challenges as ordinary self-employed people without disabilities, but the main concern is joband workplace stability. $50 \%$ of self-employed people with disabilities surveyed have a stable job and in terms of ownership, $40 \%$ is equity, for example, farmers own land, and for small businesses, household production is carried out at home or in the yard; $26.6 \%$ are rented including renting space in large markets and service centers; the remaining $34 \%$ is joint property with family members.

However, the reason for the lack of permanent workplace (50\%) is due to the high cost of rents and lack of suitable flats or space. Job and workplace stability determine their income or revenue and its percentage (for example, due to the relocation of Ts's kiosk who is one of our survey participants, there was a decrease in the number of purchases, an increase in transportation prices, a loss of sales, and shrinkage in revenue). Therefore, job stability for self-employed people with disabilities is the most important issue, and one of the state mechanisms to increase employment is to focus more on that pressing issue such as workplace and its cost. In contrast, the problems of people with stable jobs and workplaces are the sales of the products and the manufactured products. Therefore, the focus is on increasing sales.

\section{Conclusion}

The 159th International Labor Organization (ILO) Convention on the Vocational Rehabilitation and Employment of People with Disabilities specifies certain norms and provides for equal access to employment, retention and promotion of people with disabilities, equal treatment, and the work is matter of personal choice that takes into account individual capabilities. In addition, Article 111.1 of the Labor Law of Mongolia (1999) stipulates that business entities and organizations with 25 or more employees shall employ people with disabilities in four or more percent of their positions. At the initiative of the government, agencies and the private sector have been working on to support the employment of people with disabilities in accordance with the law, but to a lesser extent. This is evident from the statistics of all employed people with disabilities. On the one hand, these people have a strong desire to work and improve their position in society, but due to negative social attitudes, unfavorable attitudes of employersand lack of infrastructure, they are stuck in a deadlock, increasing the number of unemployed and relying on welfare. Whereas, within the framework of social responsibility and legal framework, people with disabilities are employed by government, non-government, and business organization, but their number is still insufficient. In particular, it is a small number compared to the growing number of people with disabilities. 
According to the 2018 survey, 76 percent of all surveyed organizations pay a monthly fee for each position that they are required to fill if they are not employed within the legal quota ${ }^{42} .55$ percent of them were private whereas 34.5 percent were government agencies ${ }^{43}$. For government agencies, this is a very poor indicator, and it is important to focus on further employment of people with disabilities, increasing their contribution to society, and maximizing their accountability.

This following conclusion is based on the survey of self-employed people with disabilities in the first quarter of 2020 . The employment or formal employment of people with disabilities of working age or over 15 years of age is already insufficient. Therefore, it is more important to look for opportunities for self-employment within the sector and to provide jobs through financial support, training and internships for those who want to become self-employed.

Being a self-employed people with disabilities has the following advantages: These include:

- $\quad$ In a time when people with disabilities have a strong interest in employment and the right to forced labor is open but limited in scope (due to poor access to infrastructure, negative social psychology, poor organizational interests and opportunities), self-employment is more appropriate and trade, production, services, agriculture, etc., there are high opportunities to find employment that suits one's interests or special needs. The law provides for tax and rent benefits for people with disabilities, and most importantly, the implementation of the law will be improved by intensifying selfemployment.

- People with disabilities who are unemployed or unable to work in society are often viewed as socially dependent, and socially discriminated against due to their lower social status and participation. Being self-employed is not only contributes to changing social attitudes and attitudes towards them, but also opens up more opportunities for personal development and growth, and creates a positive atmosphere for other people and society.

- $\quad$ The maximization in the number of self-employed people with disabilities will contribute to the activation of governmental and non-governmental organizations working in this field and to the clarification of policies, programs that intended to the special groups just like people with disabilities in society. For example, the expansion and regularization of training for enterpriser will increase the number of people with disabilities, improve their skills, support their livelihoods, and open up opportunities for them to gain a foothold in the market.

- $\quad$ Self-employment requires a certain amount of knowledge, education, experience and skills, and the process of guiding and motivating individuals to acquire a profession tailored to their specific needs will be intensified. Again, the role, policies, programs and plans of governmental and non-governmental organizations working in this area are important. Especially for them in rural areas.

In conclusion: first, for the people with disabilities, there is an urgent need to live and work independently in society, regardless of disability. This desire can be addressed based on the interests of PWDs and the promotion of sustainable employment. Second, even if those with disabilities have stable jobs, they can be supported to improve their market position; for example, by directing the activities of governmental, non-governmental, and business organizations to provide traders and entrepreneurs with marketing and maximization sales knowledge and skills. During the survey interviews, people with disabilities who are involved in trade expressed their interest in actively participating in shortterm sales training. Third, there is an urgent need for government support to increase the number of self-employed people with disabilities, and there is a positive trend in declining the number of people living on social welfare, or reduce the cost. Fourth, an increase in the number of self-employed people will disabilities will help reduce unemployment and poverty nationwide and ease negative social attitudes towards people with disabilities.

\section{Reference:}

Ministry of Labor and Social Welfare, National Agency for Development of People with Disabilities, Data Sheet for People with Disabilities, UB 2019

Ministry of Labor and Social Welfare, General Agency for Development of People with Disabilities, Policy and activities to support the development of people with disabilities in Mongolia, UB 2019

Ministry of Labor and Social Welfare, JICA, "Issues for People with Disabilities: Policies and Activities 2019", UB 2019

\footnotetext{
${ }^{42}$ Business entities and organizations with 25 or more employees shall employ people with disabilities or dwarfs in four or more percent of their positions,Labor Law of Mongolia,111.1, 1999.

${ }^{43}$ Labor and Social Welfare Research Institute, Disability Studies as an Interdisciplinary Science, Proceedings of the Scientific Conference, 2018, p.247.
}

108 
Resolution on Statistics on Labor, Employment and Under-Employment-I, 19th Conference of the Mongolian Academy of Sciences, 2013

Measuring the Informal Sector and Informal Employment, ILO-2013 11. Employment Handbook, ILO, 2015

Decent Employment and Sustainable Development Goals: A Guide to Labor Market Indicators for Sustainable Development Goals, ILO 2018.

Labor Law of Mongolia, 1999,

Personal Income Tax Law, 2019

Government Informal Employment Policy, 2006

National Statistical Office, Methodology for Calculating Employment Statistics, 2019

National Statistical Office https://www.1212.mn/

Central Labor Verification Commission under the General Department of Social Insurance http://www.ndaatgal.mn/v1/view/1192

IV Asia-Pacific Congress for Community-Based Development of People with Disabilities, Member of Parliament D. Oyunkhorol, "Reform of Mongolia's legal environment for an inclusive society for all people with disabilities in the framework of the Sustainable Development Goals and the implementation of the UN Convention on the Rights of People with Disabilities", UB, 2019

Disability Studies as an Interdisciplinary Science, Proceedings of the Scientific Conference, 2018

General Agency for Development of People with Disabilities, Policy Implementation Agency, http://www.mlsp.gov.mn/op/more/id/73

Increase pensions for people with disabilities, December 11, 2018, Unuudur newspaper http://unuudur.mn/

IV Asia-Pacific Congress for Community-Based Development of People with Disabilities, Plenary Session Report, UB, 2019 